\title{
STATUS NUTRISI PASIEN GAGAL GINJAL KRONIS DENGAN DIABETES MELLITUS DAN NON-DIABETES MELLITUS
}

\author{
Diyah Candra Anita ${ }^{1}$
}

\begin{abstract}
${ }^{1}$ Prodi Ilmu Keperawatan,Universitas 'Aisyiyah YogyakartaJl. Ring Road Barat No. 63 Mlangi Nogotirto
\end{abstract} Gamping Sleman Yogyakarta, Hp. 0818294575,Email: diyah.candra@yahoo.com

\begin{abstract}
Background:Malnutrition is a common problem in chronic renal failure (CRF) patients with or without Diabetes Mellitus (DM). An assessment of nutritional status in CRF patients is encouraged to see the level of its severity. The general parameters for assessing nutritional status are serum albumin and hemoglobin.

Objective:The objective of this research was to investigate the differences on thenutritional status of CRF patients with Diabetes Mellitus (DM) compared to those without DM at PKU Muhammadiyah Hospital Yogyakarta.

Methods:This was a comparative descriptive research applying accidental sampling and was conducted for 6 months (June-November 2014). The main measuring devices were patients' medical records and laboratory results of albumin and hemoglobin levels. Sampleof this study consisted of 30 respondents. Independent t-test was applied to analyze the differences of albumin and hemoglobin levels in both groups.

Result:The test result showed that the albumin $(p=0.917)$ and hemoglobin levels $(p=0.168)$ of CRF patients without $\mathrm{DM}$ and that of $\mathrm{CRF}$ patients with $\mathrm{DM}$ were not significantly different.

Conclusion:CRF patients with and without DM had low level of albumin and hemoglobin. Nurses shouldbe more careful in regulating fluidbalance to reduce pulmonary edema.
\end{abstract}

Keywords:Chronic Renal Failure (CRF), diabetes mellitus(DM), albumin, hemoglobin

\section{PENDAHULUAN}

Gagal Ginjal Kronis (GGK) merupakan keadaan di mana terjadi penurunan fungsi ginjal yang cukup berat secara perlahanlahan (menahun). Penyakit ini bersifat progresif dan biasanya tidak bisa pulih kembali (irreversible). ${ }^{(1)}$

Prevalensi penyakit GGK meningkat setiap tahunnya. Berdasarkan Pusat Data dan Informasi Perhimpunan Rumah Sakit (PDPERSI), jumlah penderita GGK diperkirakan 50 orang per satu juta penduduk. Selama kurun waktu dari tahun 1999 hingga 2004, terdapat 16,8\% dari populasi penduduk usia 20 tahun mengalami penyakit GGK. ${ }^{(2)}$
Etiologi utama penyakit GGK adalah diabetes mellitus (44\%), tekanan darah tinggi (27\%), glomerulonefritis (10\%), dan lain-lain (19\%). ${ }^{(1)}$ Diabetes Mellitus (DM) merupakan penyebab GGK, yaitu sekitar 30\% dari DM tipe-1 dan 40\% dari DM tipe-2. Tanda-tanda pada fase awal terkena DM tidak diketahui. Gejala tersebut muncul setelah 10 tahun menderita DM tipe-1 atau 5 sampai 8 tahun setelah menderita DM tipe-2. ${ }^{(3)}$ Penurunan status gizi merupakan bagian dari progresivitas GGK. Hal ini disebabkan adanya gangguan metabolisme energi dan protein; ketidaknormalan hormonal; asupan energi yang rendah; adanya gangguan gastrointestinal, seperti anoreksia, mual, dan muntah; diit yang ketat, serta kadar ureum 
yang tinggi. Malnutrisi dapat meningkatkan angka kesakitan dan kematian pada pasien GGK. ${ }^{(4)}$

Nefropati Diabetikum merupakan komplikasi yang ditimbulkan akibat DM. Kadar gula darah yang tinggi (hiperglikemia) yang terjadi secara kronis, secara perlahan akan merusak membran penyaring ginjal yaitu, capsula Bowman. Hal tersebut akan mengakibatkan protein rusak sehingga terjadi kebocoran protein pada urin (albuminuria). Kerusakan ginjal akibat DM juga akan menyebabkan menurunnya produksi hormon eritropoetin yang merupakan prekursor pembentukan hemoglobin. Hormon eritropoeitin 90\% diproduksi di ginjal. Kondisi tersebut akan berakibat pada kadar albumin dan hemoglobin serum sebagai salah satu prediktor progresivitas penyakit GGK. Hal inilah yang menyebabkan terjadinya malnutrisi pada pasien GGK. ${ }^{(5)}$

Tujuan umum dalam penelitian ini adalah untuk mengetahui perbedaan status nutrisi pada pasien GGK dengan DM maupun nonDM, dengan mengkaji kadar albumin dan hemoglobin di ruang rawat inap RS PKU Muhammadiyah Yogyakarta.

\section{BAHAN DAN CARA PENELITIAN}

Penelitian ini merupakan penelitian observasional komparasi dengan rancangan cross-sectional dengan penggunaan data sekunder berupa rekam medik laboratorium untuk biokimiawi darah yaitu albumin dan hemoglobin. Populasi dalam penelitian ini adalah seluruh pasien GGK yang dirawat di IRNA kelas III RS PKU Muhammadiyah Yogyakarta. Karakteristik sampel yaitu berada pada rentang usia $\geq 20$ tahun, belum menjalankan terapi hemodialisa, dan dapat berkomunikasi dengan baik. Metode pengambilan sampel dilakukan dengan purposive sampling selama 6 bulan (JuniNovember 2014), pada pagi hari. Uji statistik independent t-test digunakan untuk mengetahui adanya perbedaan kadar albumin dan kadar hemoglobin serum antara kelompok pasien GGK dengan DM dan kelompok pasien non-DM. Uji normalitas menggunakan Saphiro Wilk, dikarenakan sampel kurang dari 50 .

\section{HASIL DAN PEMBAHASAN}

Penelitian ini sudah mendapatkan izin dari Komisi Etik Universitas 'Aisyiyah Yogyakarta. 
Tabel 1. Data Demografi Responden Secara Umum

\begin{tabular}{|c|c|c|c|c|c|}
\hline \multicolumn{2}{|c|}{ No. Variabel } & \multicolumn{2}{|r|}{ Jumlah } & \multicolumn{2}{|c|}{$\%$} \\
\hline \multicolumn{6}{|c|}{ 1. Usia responden } \\
\hline & 18-29 tahun & \multirow{2}{*}{\multicolumn{2}{|c|}{$\begin{array}{r}1 \\
11\end{array}$}} & \multicolumn{2}{|c|}{3,30} \\
\hline & $30-45$ tahun & & & \multicolumn{2}{|c|}{36,70} \\
\hline & 46-59 tahun & \multicolumn{2}{|r|}{11} & \multicolumn{2}{|c|}{36,70} \\
\hline & $60-80$ tahun & \multicolumn{2}{|r|}{7} & \multicolumn{2}{|c|}{23,30} \\
\hline \multicolumn{6}{|c|}{ 2. Jenis kelamin } \\
\hline & Laki-laki & \multirow{2}{*}{\multicolumn{2}{|c|}{$\begin{array}{l}17 \\
13\end{array}$}} & \\
\hline & Perempuan & & & \multicolumn{2}{|c|}{43,30} \\
\hline \multicolumn{6}{|c|}{ 3. Penyakit penyerta diabetes } \\
\hline & GGK non-diabetes & & 19 & \\
\hline & GGK dengan diabetes & \multicolumn{2}{|r|}{11} & & \\
\hline \multicolumn{4}{|c|}{ 4. Klasifikasi hipertensi } & \multicolumn{2}{|c|}{36,70} \\
\hline & Prehipertensi & \multirow{2}{*}{\multicolumn{2}{|c|}{$\begin{array}{l}6 \\
6\end{array}$}} & \multirow{2}{*}{\multicolumn{2}{|c|}{$\begin{array}{l}20,00 \\
20.00\end{array}$}} \\
\hline & Hipertensi stage 1 & & & & \\
\hline & Hipertensi stage 2 & \multicolumn{2}{|r|}{18} & \multicolumn{2}{|c|}{60,00} \\
\hline & Jumlah total & & 30 & \multicolumn{2}{|c|}{100,00} \\
\hline \multicolumn{6}{|c|}{ Tabel 2. Distribusi Frekuensi Tekanan Darah Responden } \\
\hline \multirow[t]{2}{*}{ No. } & \multirow[t]{2}{*}{ Variabel } & \multicolumn{2}{|c|}{ TD sistolik } & \multicolumn{2}{|c|}{ TD diastolik } \\
\hline & & Mean & SD & Mean & SD \\
\hline 1. & Responden secara keseluruhan & 163,20 & 28,01 & 95,83 & 3,84 \\
\hline \multicolumn{6}{|c|}{ 2. Usia responden } \\
\hline & $30-45$ tahun & 164,27 & 29,57 & 98,00 & 17,96 \\
\hline & 46-59 tahun & 153,64 & 27,67 & 90,91 & 21,66 \\
\hline & $60-80$ tahun & 174,14 & 26,49 & 99,57 & 27,41 \\
\hline & Jenis kelamin & & & & \\
\hline & Laki-laki & 160,53 & 25,38 & 96,82 & 19,40 \\
\hline & Perempuan & 166,69 & 31,84 & 94,54 & 23,80 \\
\hline & Penyakit diabetes & & & & \\
\hline & GGK non-DM & 167,05 & 28,43 & 93,53 & 17,85 \\
\hline & GGK diabetes & 156,55 & 27,26 & 99,82 & 26,16 \\
\hline
\end{tabular}

Tabel 3. Distribusi Frekuensi Kadar Hemoglobin Responden

\begin{tabular}{ccccc}
\hline No. & Kadar hemoglobin $(\mathbf{g r} / \mathbf{d L})$ & $\mathbf{N}$ & $\%$ \\
\hline 1. & Rendah (L: $<13 \mathrm{gr} / \mathrm{dL} ; \mathrm{P}:<12 \mathrm{gr} / \mathrm{dL})$ & 29 & 96,70 \\
2. & Normal (L: $14-18 \mathrm{gr} / \mathrm{dL} ; \mathrm{P}: 12-16 \mathrm{gr} / \mathrm{dL})$ & 1 & 3,30 \\
\hline & Total & 30 & 100,00 \\
\hline
\end{tabular}

Tabel 4. Rerata Kadar Hemoglobin Responden

\begin{tabular}{|c|c|c|c|c|c|}
\hline \multirow[t]{2}{*}{ No. } & \multirow[t]{2}{*}{ Variabel } & \multicolumn{4}{|c|}{ Kadar hemoglobin (gr/dL) } \\
\hline & & Mean \pm SEM & SD & Min & $\operatorname{Max}$ \\
\hline 1. & $\begin{array}{l}\text { Responden secara } \\
\text { keseluruhan }\end{array}$ & $8,92 \pm 0,40$ & 2,21 & 6,20 & 15,40 \\
\hline \multirow[t]{4}{*}{2.} & Usia responden & & & & \\
\hline & $30-45$ tahun & $8,43 \pm 0,48$ & 1,58 & 6,20 & 10,90 \\
\hline & 46-59 tahun & $9,23 \pm 0,56$ & 1,85 & 7,00 & 13,40 \\
\hline & $60-80$ tahun & $9,49 \pm 1,31$ & 3,46 & 6,30 & 15,40 \\
\hline \multirow[t]{3}{*}{3.} & Jenis kelamin & & & & \\
\hline & Laki-laki & $8,83 \pm 0,50$ & 2,07 & 6,30 & 13,40 \\
\hline & Perempuan & $9,03 \pm 0,68$ & 2,46 & 6,20 & 15,40 \\
\hline \multirow[t]{3}{*}{4.} & Penyakit diabetes & & & & \\
\hline & GGK non-DM & $8,49 \pm 0,46$ & 1,99 & 6,20 & 13,40 \\
\hline & GGK DM & $9,66 \pm 0,74$ & 2,45 & 6,90 & 15,40 \\
\hline
\end{tabular}


Tabel 5. Distribusi Frekuensi Kadar Albumin Responden

\begin{tabular}{clcc}
\hline No. & \multicolumn{1}{c}{ Kadar Albumin (gr\%) } & $\mathbf{N}$ & $\%$ \\
\hline 1. & Rendah (<3,5-5,0 gr\%) & 12 & 40,00 \\
2. & Normal $(3,5-5,0$ gr\%) & 18 & 60,00 \\
\hline & Total & 30 & 100,00 \\
\hline
\end{tabular}

Tabel 6. Rerata Kadar Albumin Responden

\begin{tabular}{|c|c|c|c|c|c|}
\hline \multirow[t]{2}{*}{ No. } & \multirow[t]{2}{*}{ Variabel } & \multicolumn{4}{|c|}{ Kadar albumin (gr\%) } \\
\hline & & Mean \pm SEM & SD & Min & Max \\
\hline 1. & $\begin{array}{l}\text { Responden secara } \\
\text { keseluruhan }\end{array}$ & $3,59 \pm 0,11$ & 0,58 & 2,10 & 4,60 \\
\hline 2. & $\begin{array}{l}\text { Usia responden } \\
\qquad \begin{array}{l}30-45 \text { tahun } \\
46-59 \text { tahun } \\
60-80 \text { tahun }\end{array}\end{array}$ & $\begin{array}{l}3,51 \pm 0,22 \\
3,63 \pm 0,15 \\
3,56 \pm 0,19\end{array}$ & $\begin{array}{l}0,73 \\
0,51 \\
0,51\end{array}$ & $\begin{array}{l}2,10 \\
2,70 \\
3,10\end{array}$ & $\begin{array}{l}4,60 \\
4,20 \\
4,50\end{array}$ \\
\hline & $\begin{array}{l}\text { Jenis kelamin } \\
\qquad \begin{array}{l}\text { Laki-laki } \\
\text { Perempuan }\end{array}\end{array}$ & $\begin{array}{l}3,67 \pm 0,13 \\
3,48 \pm 0,18\end{array}$ & $\begin{array}{l}0,55 \\
0,63\end{array}$ & $\begin{array}{l}2,10 \\
2,40\end{array}$ & $\begin{array}{l}4,50 \\
4,60\end{array}$ \\
\hline 4. & $\begin{array}{l}\text { Penyakit diabetes } \\
\text { GGK non-DM } \\
\text { GGK DM }\end{array}$ & $\begin{array}{l}3,58 \pm 0,15 \\
3,60 \pm 0,15\end{array}$ & $\begin{array}{l}0,64 \\
0,50 \\
\end{array}$ & $\begin{array}{l}2,10 \\
3,00 \\
\end{array}$ & $\begin{array}{l}4,50 \\
4,60 \\
\end{array}$ \\
\hline
\end{tabular}

Tabel 7. Uji Beda Kadar Hemoglobin dan Kadar Albumin

\begin{tabular}{clcc}
\hline No. & Variabel & $\boldsymbol{p}$-value & Interpretasi \\
\hline 1. & Kadar hemoglobin & 0,168 & Berbeda tidak bermakna \\
2. & Kadar albumin & 0,917 & Berbeda tidak bermakna \\
\hline
\end{tabular}

Gagal ginjal kronik (GGK) merupakan sebuah kondisi kerusakan ginjal yang dapat diketahui dengan pemeriksaan urinasi, radiologi, maupun histologi. Diagnosis penyakit GGK ditegakkan apabila pasien memiliki glomerular filtration rate (GFR) kurang dari $60 \mathrm{~mL} /$ menit/1,73 $\mathrm{m}^{2}$ dalam kurun waktu lebih dari sama dengan tiga bulan. ${ }^{(3)}$

Gagal ginjal kronik (GGK) adalah penyakit yang bisa diderita oleh semua rentang usia, mulai dari anak-anak, remaja, dan lansia. Hal ini sesuai dengan hasil penelitian yang tercantum pada tabel 1 , bahwa dalam penelitian ini responden dengan GGK dapat ditemukan pada usia dewasa muda $(3,30 \%)$, dewasa madya
$(36,70 \%)$, dewasa tua $(36,70 \%)$, dan lansia $(23,30 \%)$.

Sebagian besar responden (96,70\%) dalam penelitian ini berusia 40 tahun ke atas. Hasil penelitian ini sesuai dengan teori yang menyebutkan bahwa fungsi ginjal akan mengalami penurunan secara progresif sejak usia 40 tahun. (7) Pada usia 60 tahun kemampuan ginjal menurun 50\% dari kapasitas fungsinya pada usia 40 tahun, yang disebabkan karena proses fisiologik berupa berkurangnya populasi nefron dan tidak adanya kemampuan regenerasi.

Data pada tabel 2 menggambarkan bahwa mayoritas responden dalam penelitian ini $(60,00 \%)$ mengalami hipertensi stage 2 , dengan tekanan darah sistolik $\geq 160 \mathrm{mmHg}$ 
dan atau tekanan darah diastolik $\geq 100$ $\mathrm{mmHg}$. Hasil penelitian ini mendukung penelitian yang menyebutkan bahwa mayoritas penderita GGK (56,70\%) menderita hipertensi. ${ }^{(8)}$ Penyakit penyerta yang paling sering menyertai GGK adalah: hipertensi (75,00\%); DM (8,00\%); DM dan hipertensi (13,00\%); dan ginjal polikistik $(4,00 \%){ }^{(6)}$

Hipertensi merupakan gangguan kesehatan yang diderita $10-30 \%$ orang dewasa di seluruh dunia. Faktor risiko hipertensi adalah faktor genetik/keturunan, pola hidup banyak mengonsumsi garam, stres, gangguan metabolisme lemak dan karbohidrat. Hipertensi dapat menyebabkan vasokontriksi pembuluh darah di ginjal, sehingga aliran darah ke ginjal berkurang. Apabila hal ini terjadi terus menerus (kronis), maka ginjal akan rusak dan tidak mampu berfungsi lagi. Kondisi inilah yang disebut sebagai gagal ginjal terminal (GGT). Penyakit GGT tidak bisa disembuhkan secara medis, namun untuk memperpanjang usia harapan hidup penderita GGT, dapat dilakukan upaya cuci darah (hemodialisa) atau transplantasi ginjal. ${ }^{(10)}$

Hasil penelitian pada tabel 3 menunjukkan bahwa mayoritas responden memiliki kadar hemoglobin yang rendah $(96,70 \%)$. Hasil tersebut diperkuat dengan data pada tabel 4 yang menunjukkan bahwa rerata kadar hemoglobin responden adalah 8,92 gr/dL. Hemoglobin dikatakan normal, jika kadar hemoglobin dalam darah berada pada rentang 14-18 gr/dL untuk laki-laki; dan 12-16 gr/dL untuk perempuan. Berdasarkan data tersebut, maka mayoritas responden mengalami anemia.

Anemia merupakan manifestasi klinik penurunan sel darah merah pada sirkulasi dan biasanya ditandai dengan penurunan konsentrasi hemoglobin ( $\mathrm{Hb})$. Anemia didefinisikan dari National Kidney Foundation Kidney Disease Outcomes Quality Initiative (NKF/K-DOQI) merupakan konsentrasi hemoglobin $(\mathrm{Hb})$ yang kurang dari $13,5 \mathrm{~g} / \mathrm{dL}$ pada laki-laki dewasa dan kurang dari 12 g/dL pada wanita dewasa. ${ }^{(11)}$ Anemia merupakan komplikasi yang sering terjadi pada gagal ginjal kronik. Insiden ini meningkat karena penurunan Glomerular Filtration Rate (GFR). Sebuah studi populasi National Health and Nutrition Examination Survey (NHANES) dari National Institutes of Health and Prevalence of Anemia in Early Renal Insufficiency (PAERI) menyebutkan bahwa insiden terjadinya anemia adalah kurang dari $10 \%$ pada GGK stadium 1 dan 2 , $20-40 \%$ pada GGK stadium 3, 50-60\% pada GGK stadium 4, dan lebih dari $70 \%$ pada GGK stadium 5. ${ }^{(12)}$

Ginjal mampu membuat hormon yang disebut sebagai eritropoietin (EPO), yang penting untuk produksi sel darah merah. Saat ginjal kehilangan fungsinya, akan mengakibatkan berkurangnya kemampuan ginjal memproduksi hormon EPO, sehingga akibatnya pasien mengalami anemia. Gejala anemia yang sering dikeluhkan adalah sesak 
nafas dan kelelahan (merasa lelah). Kondisi anemia pada beberapa pasien akan menjadi semakin parah, sehingga menyebabkan nyeri dada dan meningkatkan risiko penyakit jantung. ${ }^{(11)}$

Diabetes mellitus adalah salah satu penyakit yang dapat menyebabkan anemia. Pasien DM seringkali dipantau secara teratur untuk mencegah terjadinya komplikasi seperti neuropati, nefropati, dan retinopati. Meskipun demikian, pemeriksaan kadar hemoglobin tidak dinilai secara rutin, padahal penurunan kadar hemoglobin sering terjadi sebelum komplikasi nefropati. ${ }^{(13)}$

Pasien dengan GGK mengalami penurunan fungsi ginjal, sehingga ginjal menjadi tidak memproduksi eritropoietin dalam jumlah cukup. Faktor lain yang memengaruhi kadar hemoglobin adalah penggunaan obat-obatan DM seperti, metformin, fibrat, thiazolidinediones, dan angiotensin-converting enzyme inhibitor. Inflamasi sistemik yang terjadi pada komplikasi mikrovaskular DM, akan menyebabkan produksi sitokin pro-inflamasi, seperti interleukin dan tissue nechrosis factor (TNF). Pelepasan kedua sitokin tersebut, akan menumpulkan kinerja dari eritropoietin pada sunsum tulang, yang merupakan tempat stimulasi prekusor erithroid. ${ }^{(13)}$

Berdasarkan tabel 7, didapatkan data bahwa tidak ada perbedaan kadar hemoglobin antara GGK dengan DM dan GGK non-DM, dengan $p$ value=0,168. Pasien yang memiliki kadar hemoglobin yang normal, diasumsikan dipengaruhi oleh kadar ureum yang tidak terlalu tinggi. ${ }^{(7)}$ Apabila kadar ureum darah tinggi, akan menimbulkan toksik uremik yang dapat menginaktifkan eritropoietin atau menekan respon sumsum tulang terhadap eritropoietin untuk menghasilkan sel darah merah. ${ }^{(9)}$

Pasien GGK baik dengan DM dan nonDM sering terjadi anemia sekitar $80-90 \%$. Penyebab utama anemia adalah berkurangnya pembentukan sel-sel darah merah, yang disebabkan oleh defisiensi pembentukan eritropoietin oleh ginjal. Faktor kedua yang ikut berperan pada anemia adalah masa hidup sel darah merah pada pasien GGK yang hanya sekitar separuh dari masa hidup sel darah merah normal (120 hari)..$^{(7)}$

Hasil penelitian pada tabel 5 . menyebutkan bahwa sebagian besar (60\%) responden memiliki kadar albumin normal, dengan nilai rerata 3,59 gr/dL. Rerata kadar albumin mendekati batas bawah nilai normal, yaitu $3,50 \mathrm{gr} / \mathrm{dL}$. Hasil penelitian pada tabel 6. menunjukkan rerata kadar albumin pada pasien GGK dengan DM adalah 3,60 gr/dL, lebih tinggi dibandingkan rerata albumin pada pasien GGK non-DM, yaitu 3,58 gr/dL. Terdapat selisih tipis terhadap kadar albumin pada kedua kelompok tersebut, yaitu 0,02 gr/dL. Hasil uji beda secara statistik pada kedua kelompok tersebut juga menunjukkan adanya hasil berbeda tidak bermakna, dengan nilai $p$ value 0,917 (tabel 7). 


\section{KESIMPULAN}

Kadar albumin dan hemoglobin pada pasien GGK non-DM dan pasien GGK dengan DM berbeda tidak bermakna. Hasil yang didapatkan pada kedua kelompok kadar hemoglobin dan albumin dibawah normal. Oleh karena itu, perlu penanganan yang lebih cermat dalam pengaturan keseimbangan cairan guna mengurangi kondisi edem pulmonal serta meminimalkan risiko cedera vaskular pada saat pelaksanaan hemodialisa.

\section{KEPUSTAKAAN}

1. Suwitra, K. Penyakit Ginjal Kronik Jakarta: FK UI; 2006.

2. Suhardjono. The Development of $A$ Continuous Ambulatory Peritoneal Dialysis Program In Indonesia. Perit Dial Int. 2008; 3: p. S59-62.

3. Iseki, K. Gender Differences in Chronic Kidney Disease. Kidney Int. 2008; 74: p. 415-417.

4. Pinna, D., Whitney. Nutrition and Diit Theraphy. 7th ed. USA: Thompson; 2008.

5. Arau'jo, D. Nutritional Parameters And Mortality In Incident Hemodyalisis Patient. J Ren Nutr. 2006; 16(1): p. 27-35.

Saryono, Handoyo. Kadar Ureum dan

6. Kreatinin Darah Pada Pasien yang Menjalani Terapi Hemodialisa di RSU Dr. Margono Purwokerto. Naskah Publikasi. 2006.
7. Chadijah, S., Wirawanni, Y. Perbedaan Status Gizi, Ureum Dan Kreatinin Pada Pasien Gagal Ginjal Kronik Dengan Diabetes Mellitus Dan Non-Diabetes Mellitus Di RSUD dr. Zainoel Abidin Banda Aceh. Skripsi. Semarang: Universitas Diponegoro; 2011.

8. Asriani, Bahar, B., Kadrianti, E. Hubungan Hipertensi Dengan Kejadian Gagal Ginjal Di Rumah Sakit Ibnu Sina Makassar Periode Januari 2011-Desember 2012. Jurnal IImiah Kesehatan Diagnosis. 2014; 4(12): p. 163-168.

9. Sherwood, L. Human Physiology: From Cell to Systems. Yusnita N, editor. Jakarta: EGC; 2011.

10. Sutanto. Cekal (Cegah dan Tangkal) Penyakit Modern Hipertensi, Stroke, Jantung, Kolesterol dan Diabetes. 1st ed. Yogyakarta: CV Andi Offset; 2010.

11. Suresh, M., Malikarjuna, R., Sharan, B., Hari, K., Shravya, K., Chandrasekhar, M. Hematological Changes in Chronic Renal Failure. IJSRP. 2012; 2(9): p. 1-4.

12. Lankhorst, C., Wish, J. Anemia In Renal Disease: Diagnosis And Management. Blood Reviews. 2010; 24: p. 39-47.

13. O'Mara, N. Anemia In Patients With Chronic Kidney Disease. Diabetes Spectrum. 2008; 21(1): p. 12-19. 